\title{
Intracellular Calcium Store and Transport of Elements in Acinar Cells of the Salivary Gland Determined by Electron Probe X-ray Microanalysis
}

\author{
Sadao SASAKI, Ikuko NAKagaki, Hirohiko Mori, \\ and Yusuke IMAI \\ Department of Physiology, Osaka Medical College, \\ Takatsuki, Osaka, 569 Japan
}

\begin{abstract}
Electron probe X-ray microanalysis using freshly frozen hydrated and dried thin sections of dog submandibular gland was performed to determine the distribution of elements and water in the acinar cells of resting and stimulating states. The results obtained are as follows: (a) The secretory granules contained high concentrations of $\mathrm{Ca}$ and $\mathrm{S}$ while high concentrations of $\mathrm{K}$ and $\mathrm{P}$ were present in the cytoplasm and/or nucleus of acinar mucous cells of the gland in the resting state. (b) With pilocarpine stimulation, the concentration of $\mathrm{Ca}$ increased in the cytoplasm and decreased in the secretory granules, while there was an increase in the concentration of $\mathrm{Na}$ and $\mathrm{Cl}$ in both the cytoplasm and secretory granules of the cells. (c) The local dry-mass fractions of acinar cells, estimated by comparing the continuum radiation of $\mathrm{X}$-ray spectrum from the frozen hydrated sections with that from the frozen dehydrated sections, were approximately 20 and $33 \%$ in the cytoplasm and secretory granules of resting acinar cells, respectively, and each value was not significantly altered under conditions of stimulation having a tendency to decrease slightly. Therefore, the passive $\mathrm{Na}$ and $\mathrm{Cl}$ influx and the cytoplasmic $\mathrm{Ca}$ flowed in from extracellular spaces and released from secretory granules, an intracellular calcium store, by secretory stimulation probably triggers the passive or active $\mathrm{Na}$ and $\mathrm{Cl}$ extrusion and consequently the osmotic water flux from the basal part of acinar cells to the secretory granules and the lumen, as well as the serial exocytosis of the granules in the luminal side of the acinar cells.
\end{abstract}

Key Words: electron probe X-ray microanalysis, dog salivary gland, pilocarpine stimulation, electrolyte transport, intracellular calcium store.

Saliva is primarily secreted in the acini of the salivary glands and is followed by a secondary process of reabsorption in the duct system (Young and MARTIN,

Received for publication June 3, 1982

佐々木貞雄, 中垣育子, 森 博彦, 今井雄介 
1971; Petersen, 1971; Imai et al., 1972). Electron microscope observations revealed that the acinar cells of these glands occupy the bulk of the cytoplasm in the form of secretory granules. It is considered that with nerve stimulation, the contents of the secretory granules of the acinar cells, amylase, mucin, and several ions as well as water, are secreted into the glandular lumen by an exocytotic mechanism (NAKagaki et al., 1978). Recent studies (Nielsen and Petersen, 1972) on the secretory process in the acinar cells of the salivary gland using tracers such as ${ }^{45} \mathrm{Ca}$ have drawn attention to the distribution of calcium and other ions in these cells and to the intracellular transport of ions in the secretory stimulating state of the glands.

We carried out electron probe X-ray microanalysis of freshly frozen dried and hydrated sections to determine the elemental distribution and concentration in the acinar cells of the salivary gland in the resting and stimulating states, with special reference to the ionic content of cytoplasm and secretory granules, using the standard albumin frozen thin sections and the calibration curves for elemental concentration-peak/back ratio (MORETON et al., 1974; DöRge et al., 1978). Preliminary reports have been made elsewhere (SASAKI et al., 1979, 1980).

\section{METHODS}

Electron probe $X$-ray microanalysis. Small pieces of submandibular gland were excised from adult dogs anesthetized with sodium thiopentobarbiturate $(30-40 \mathrm{mg} / \mathrm{kg}$ ) given intravenously. The specimens from the glands of normal and low $\mathrm{Na}, \mathrm{Cl}(\mathrm{Na} 95, \mathrm{Cl} 85 \mathrm{~mm} / \mathrm{kg}$ water) extracellular conditions in the resting or secretory stimulating states (pilocarpine $1 \mathrm{mg} /$ adult dog, $1 \mathrm{~min}$ after intravenous injection), were mounted in Krebs-Henseleit solution containing $20 \%$ bovine serum albumin (BSA), on copper specimen holders, and rapidly frozen by pressing against the wall of a copper block which had been pre-cooled to $-196^{\circ} \mathrm{C}$ in liquid nitrogen. Frozen sections were cut into $100-200 \mathrm{~nm}$ at $-130^{\circ} \mathrm{C}$ with glass knives on a Frozen Thin Sectioner of Porter-Blum MT-2 ultramicrotome, placed on pre-cooled gold or copper grids covered with collodion film and flattened on the grids to be stamped with liquid nitrogen-chilled, polished copper rods. Both gold and copper grids were used because the $\mathrm{Cu} \mathrm{L}$ peak and the $\mathrm{Au} \mathrm{M}$ peak interfered with the $\mathrm{Na}$ peak and $P$ and $S$ peaks in the energy dispersive spectrum of $X$-ray microanalysis, respectively. In some cases, nickel and titanium grids were also used. For X-ray microanalysis of frozen dried sections, the grids with frozen thin sections were transferred to a liquid nitrogen-chilled glass vial and transported in liquid nitrogen to an FTS freezing-drier (FTS Systems, Inc., Stone Ridge, N. Y., U. S. A.) where the frozen thin sections were dried at $-85^{\circ} \mathrm{C}$ by pumping at $10^{-3}-10^{-4}$ Torr overnight. The grids with frozen dried thin sections were carbon-coated and loaded onto a cold stage of a Hitachi H-500 transmission electron microscope modified to accept a Kevex Si (Li) X-ray detector (Kevex Corp., Burlingame, Calif., U. S. A.) inter- 
faced with Kevex 5100 or 7000 multichannel analyzer. The probe currents used ranged from $10^{-9}-10^{-10} \mathrm{~A}$ and the probe diameter was $100 \mathrm{~nm}$. The detecting time for obtaining X-ray spectra was $100 \mathrm{sec}$. For the X-ray microanalysis of frozen hydrated sections, immediately after the sectioning of frozen thin sections, the grids with frozen sections were transferred in the cryochamber of the Frozen Thin Sectioner of the ultramicrotome to a cooling specimen holder of Hitachi H-500 electron microscope (H500lC), which had been pre-cooled to $-130^{\circ} \mathrm{C}$ with liquid nitrogen. The tip of the cooling specimen holder with frozen hydrated sections was withdrawn inside a metal tube pre-cooled with liquid nitrogen and then transported in liquid nitrogen to the cold stage of electron microscope to avoid the absorption of moisture from the atmosphere (GuPTA et al., 1977). The X-ray microanalysis was performed at $-130^{\circ} \mathrm{C}$ as described above, and then inside the column of the electron microscope, the specimens were warmed and dehydrated by charging an electric current and by heating the tip of the cooling specimen holder. The X-ray microanalysis of frozen dehydrated sections was also performed to determine the values of the local dry-mass fractions of the cells (GUPTA et al., 1977, 1978). The measurement of elemental concentrations in the spots of the specimens was performed according to the methods reported by other workers (SomLYo et al., 1977; GUPTA et al., 1977; DöRGE et al., 1978), using the characteristic peak X-ray continuum ratio of the energy dispersive spectrum obtained. The concentration was read off the graph of the elemental concentration-peak/back ratio, applying the peak/back ratios of the four elements $(\mathrm{Ca}, \mathrm{K}, \mathrm{Na}, \mathrm{Cl})$ from the X-ray spectra of acinar mucous cells in the resting and secretory stimulating state to the standard curve of the graph which was made using X-ray spectra from the standard albumin frozen thin sections containing various concentrations of elements and bovine serum albumin. The concentration of the extracellular space of acinar mucous cells which was immersed with Krebs-Henseleit solution containing $20 \%$ albumin, was also read off the graph, and our quantitative X-ray microanalysis was always checked up. Calculation of elemental concentrations was performed by means of special utility programs for a few kinds of microcomputer.

Conventional electron microscopy. The specimens from animals in the resting state were fixed successively in glutaraldehyde and osmium, dehydrated in ethanol and embedded in Epon 812. After ultrathin sectioning with an ultramicrotome, the specimens were stained with uranyl acetate and lead citrate and observed under an electron microscope at an accelerating voltage of $100 \mathrm{kV}$.

\section{RESULTS}

\section{Electron microscopy}

Figure 1 shows the transmission electron micrographs of a conventionally fixed and embedded ultrathin section (Fig. 1A) and freshly frozen dried sections (Fig. 1B, C) of resting dog submandibular glands. The acinus of the gland is com- 

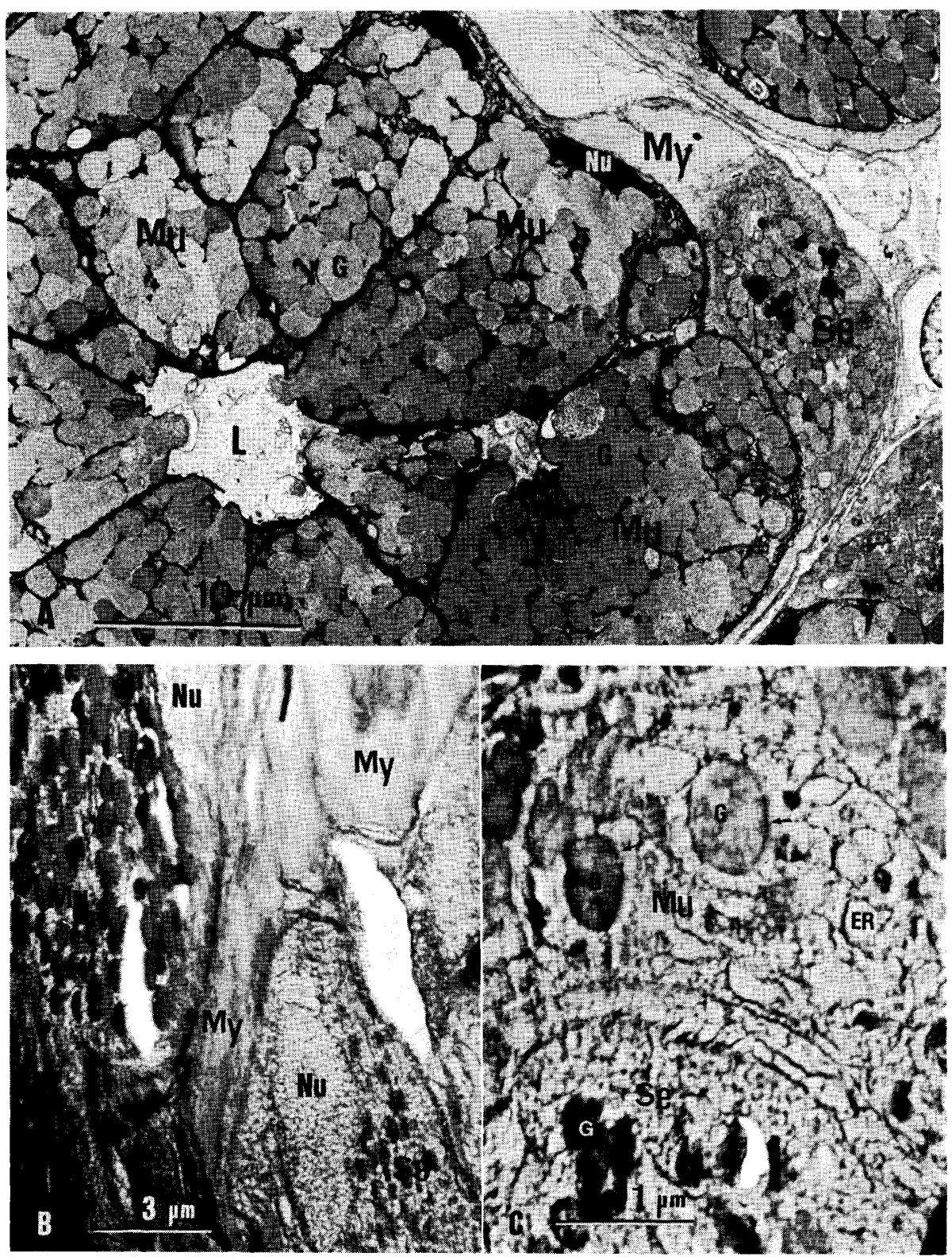

Fig. 1. Electron micrographs of conventionally Epon 812 embedded and freshly frozen dried thin sections of dog submandibular glands in the resting state. A: a conventional transmission electron micrograph of an acinus of submandibular gland. The micrograph shows that the serous (Se) and myoepithelial cells (My) lie on the basal side of mucous cells $(\mathrm{Mu})$ which surround the glandular lumen (L) of acinus and are occupied in the bulk of cytoplasm by secretory granules $(G) . \quad \times 2,700$. Bar, $10 \mu \mathrm{m}$. B: a scanning transmission electron micrograph of a frozen dried thin section cut from the freshly frozen sub- 
posed of serous cells, myoepithelial cells making up the demilune at the basal parts of acinus and mucous cells surrounding the glandular lumen. The mucous cells are occupied in the bulk of the apical cytoplasm by numerous secretory granules, some of which have been discharged into the glandular lumen by an exocytotic mechanism. Relatively electron dense small granules are also seen in the serous cells which are located in contact with the basolateral plasma membrane of mucous cells (Fig. 1A). The scanning transmission electron microscope images of freshly frozen dried sections of submandibular glands are shown in Fig. 1B and C. The structural details in the image are consistent with those seen under a conventional electron microscope (Fig. 1B). The contrast is good and the major cellular features, even the membranes of secretory granules of mucous cells are clearly evident (Fig. 1C).

\section{$X$-ray microanalysis of frozen dried sections}

The X-ray spectra from areas in the cytoplasm, secretory granules, nucleus and $20 \%$ BSA immersed baso-lateral extracellular spaces of mucous cells in the resting state are shown in Fig. 2a, b, c, and d. The spectra show the presence of a large concentration of $\mathrm{K}$ and $\mathrm{P}$ in the cytoplasm and relatively high concentrations of $\mathrm{Ca}$, $\mathrm{K}, \mathrm{Cl}, \mathrm{S}$, and $\mathrm{Na}$ in the secretory granule of the cell. Our X-ray microanalysis of the nucleus and the mitochondrial matrix presented similar spectra to that seen in the cytoplasm, except that the nucleus contained a larger quantity of P (Fig. 2c). The $\mathrm{Na}$ peak in the spectrum of secretory granule was displaced slightly toward the $\mathrm{Mg}$ peak of a higher X-ray energy level. This spectrum (Fig. 2b) shows that the secretory granules do contain some $\mathrm{Mg}$. In our X-ray spectra of the extracellular space, high $\mathrm{Na}$ and $\mathrm{Cl}$ peaks were present (Fig. 2d). The X-ray spectra from areas in the cytoplasm and secretory granules of mucous cells in the stimulating state of normal and low $\mathrm{Na}, \mathrm{Cl}$ extracellular conditions are shown in Fig. 3a, $\mathrm{b}, \mathrm{c}$, and $\mathrm{d}$. The spectra from the glands of normal extracellular condition show the presence of the $\mathrm{Ca}, \mathrm{Cl}$, and $\mathrm{Na}$ peaks in addition to the $\mathrm{K}$ and $\mathrm{P}$ peaks in the cytoplasm, and the $\mathrm{K}, \mathrm{Cl}, \mathrm{S}, \mathrm{Na}$, and small $\mathrm{Ca}$ peaks in the secretory granule of the cell. These elements are also present in the glandular lumen and/or exocytotic granules of mucous cell, which have discharged their contents into the lumen (Fig. $3 \mathrm{a}, \mathrm{b})$. The spectra from the glands of low $\mathrm{Na}, \mathrm{Cl}$ extracellular condition show a smaller peak and a much larger peak of $\mathrm{Ca}$ in the cytoplasm and secretory granule,

mandibular gland. The micrograph also shows that the serous (Se) and myoepithelial (My) cells are in contact with the mucous cells $(\mathrm{Mu})$ which have large electron dense secretory granules $(\mathrm{G})$ in the cytoplasm. The nuclei $(\mathrm{Nu})$ of acinar cells are also visible. $\times 5,100$. Bar, $3 \mu \mathrm{m}$. C: a high magnification scanning transmission electron micrograph of a frozen dried thin section of the acinar cells. The micrograph shows that the mucous cell $(\mathrm{Mu})$ containing the large secretory granules $(\mathrm{G})$ and the endoplasmic reticulum (ER) in the cytoplasm is in contact with the serous cell (Se) in which relatively small dense secretory granules $(G)$ are visible. The membranes of secretory granules of mucous cell can be identified (arrows). $\times 17,500$. Bar, $1 \mu \mathrm{m}$. 


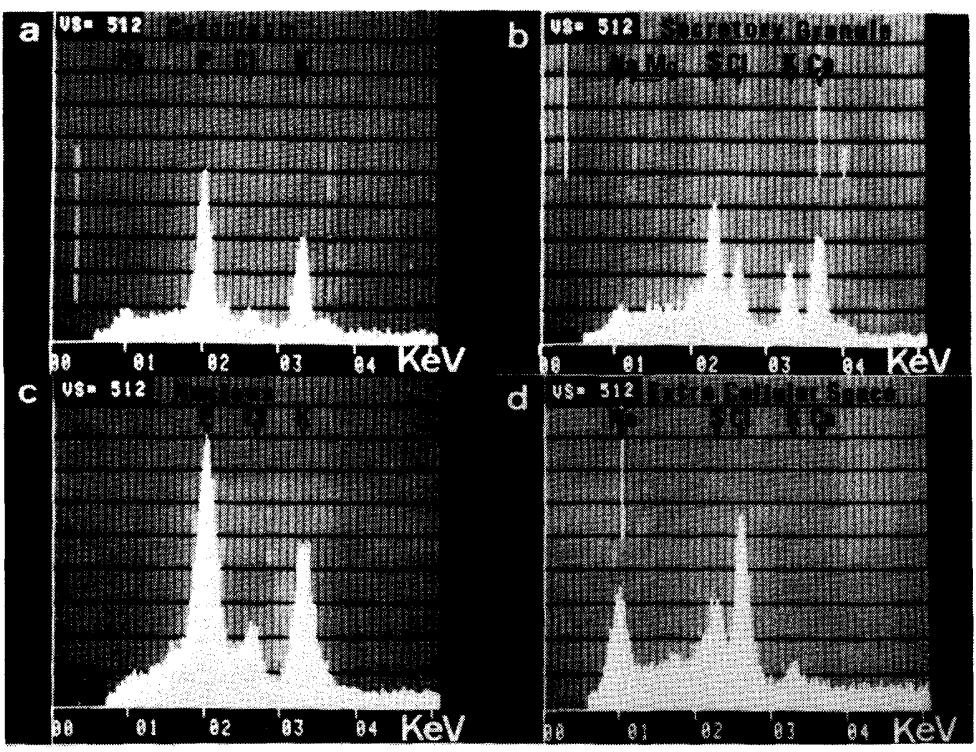

Fig. 2. Representative energy dispersive X-ray spectra of cytoplasm, secretory granule, nucleus and extracellular space of acinar mucous cells of the resting gland. The specimens were prepared as in Fig. 1B and C. X-ray spectra were taken with a beam of $75 \mathrm{kV}$, probe diameter $100 \mathrm{~nm}$ and probe current $0.1-1 \mathrm{nA}$ for $100 \mathrm{sec}$ livetime. Extraneous small peaks of $\mathrm{Au} \mathrm{M}$ and $\mathrm{Si}$, which originate in the gold grid and the X-ray detector are not subtracted in the spectra. a: X-ray spectrum of cytoplasm. Note the high $\mathrm{K}$ and $\mathrm{P}$ peaks in the cytoplasm of acinar mucous cell. The small $\mathrm{Na}$ and $\mathrm{Cl}$ peaks are also present in the spectrum. b: X-ray spectrum of secretory granules. Note the relatively high $\mathrm{Ca}, \mathrm{K}$, $\mathrm{Cl}$, and $\mathrm{S}$ peaks and the $\mathrm{Na}$ peak in the secretory granules of acinar mucous cell. $\mathrm{c}: \mathrm{X}$ ray spectrum of nucleus. Note the high $\mathrm{K}$ and the much higher $\mathrm{P}$ peaks in the nucleus of acinar mucous cell. The small $\mathrm{Cl}$ peak is also present in the spectrum. $\mathrm{d}$ : X-ray spectrum of extracellular space. The large $\mathrm{Na}$ and $\mathrm{Cl}$ peaks are seen in the extracellular space of acinar cells. The small $\mathrm{Ca}$ and $\mathrm{K}$ peaks and the $\mathrm{S}$ peak are also found in the spectrum.

respectively and the smaller peaks of $\mathrm{Na}$ and $\mathrm{Cl}$ in both cytoplasm and secretory granules to compare with those from the glands of normal extracellular condition (Fig. 3c, d).

\section{Estimation of local dry-mass fractions}

Since the main body of our measurements is concerned with the sections and standards in the dried states, the primary results are actually dry-weight concentration. However, they may be designated as suggested by GupTA et al. (1977). Dry-weight concentration $c_{\mathrm{d}}$ is converted to wet-weight concentration $c_{\mathrm{w}}$ by means of the equation

$$
c_{\mathrm{w}}=f_{\mathrm{d}} c_{\mathrm{d}}
$$




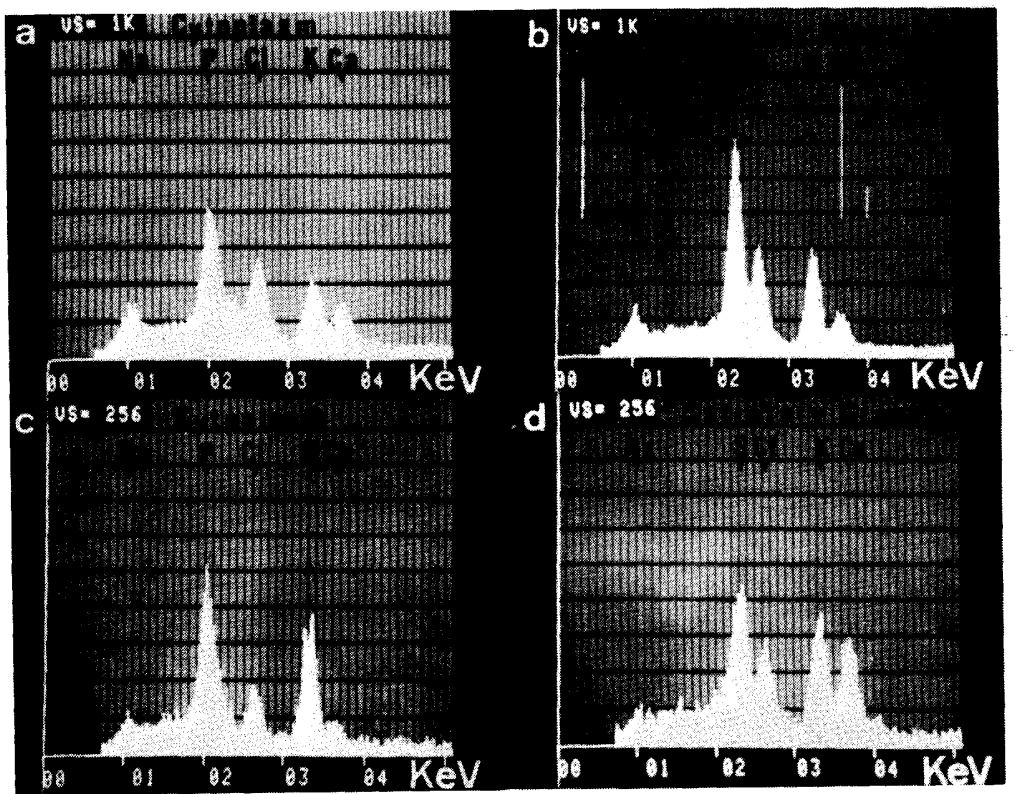

Fig. 3. Representative energy dispersive X-ray spectra of cytoplasm and secretory granule of acinar mucous cells of submandibular gland of normal and low $\mathrm{Na}, \mathrm{Cl}$ extracellular conditions in a stimulating state (pilocarpine, $1 \mathrm{mg} /$ adult dog intravenously). The specimens were prepared and X-ray spectra were taken as in Fig. 2. a: X-ray spectrum of cytoplasm in normal extracellular condition. Note the increase of $\mathrm{Na}, \mathrm{Cl}$, and $\mathrm{Ca}$ concentration of the cytoplasm in the secretory stimulating state. b: X-ray spectrum of secretory granules in normal extracellular condition. Note the increase of $\mathrm{Na}$ concentration and decrease of $\mathrm{Ca}$ concentration of the secretory granules in the secretory stimulating state. c: X-ray spectrum of cytoplasm in low $\mathrm{Na}, \mathrm{Cl}$ extracellular condition. Note the smaller peaks of $\mathrm{Na}, \mathrm{Cl}$, and $\mathrm{Ca}$ to compare with those of normal extracellular condition. d: X-ray spectrum of secretory granules in low $\mathrm{Na}, \mathrm{Cl}$ extracellular condition. Note the much larger peak of $\mathrm{Ca}$ and the smaller peaks of $\mathrm{Na}$ and $\mathrm{Cl}$ to compare with those of normal extracellular condition.

where $f_{\mathrm{d}}$ is the local dry-mass fraction. The local dry-mass fractions of acinar cells of salivary gland were estimated by comparing the continuum radiation of spectrum from the frozen hydrated sections $\left(-130^{\circ} \mathrm{C}\right)$ with that from the frozen dehydrated sections. The scanning transmission electron micrographs of a frozen hydrated section revealed few details of the cellular structure (Fig. 4A). Figure 4B shows that the image contrast in the section enhanced gradually while the specimen was warmed from -130 to $-80^{\circ} \mathrm{C}$ and dehydrated by charging an electric current and by heating the tip of the cooling specimen holder, and dramatic improvement in contrast and spatial resolution occurred after the complete removal of water at $0^{\circ} \mathrm{C}$ and the secretory granules of acinar cells were clearly identifiable as shown in Fig. 1. Figure 5 shows the X-ray spectra of the cytoplasm and secretory granules of mucous cells from frozen hydrated sections (Fig. 5a and b) and dehydrated sections 


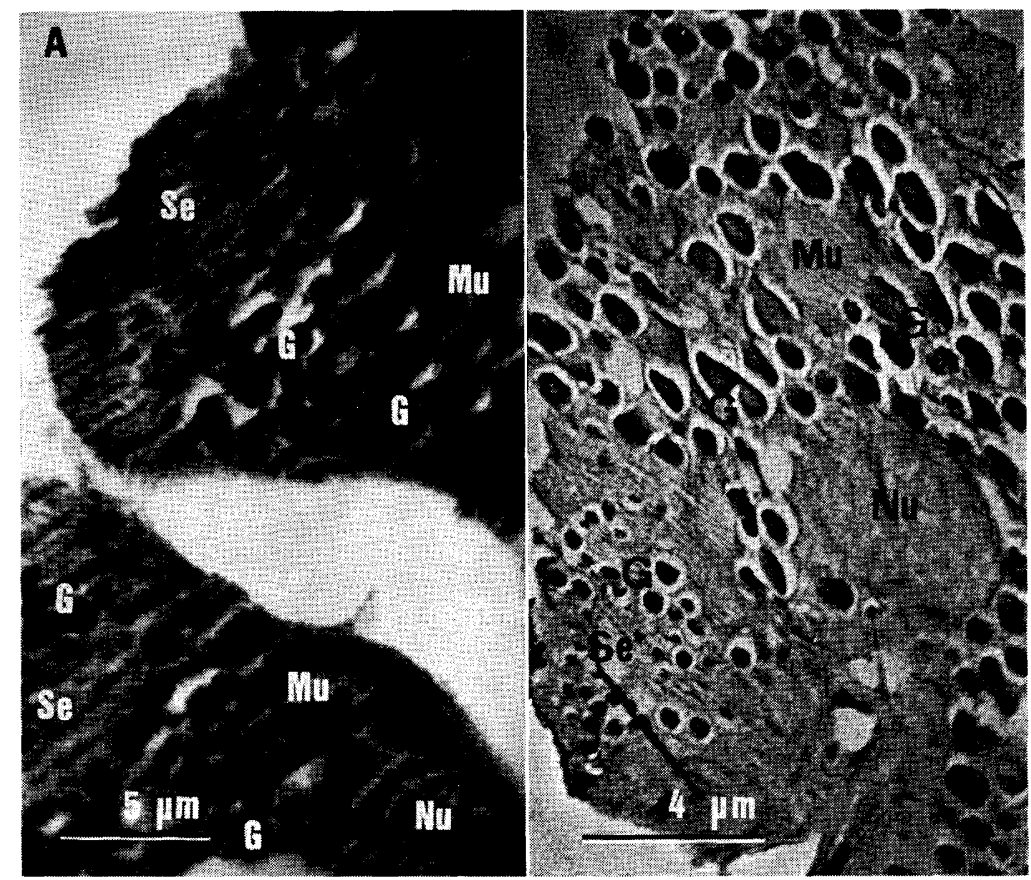

Fig. 4. Electron micrographs of frozen hydrated and dehydrated sections of dog submandibular glands in the resting state. The specimens were prepared as described in METHODS. A: a scanning transmission electron micrograph of a frozen hydrated section $\left(-130^{\circ} \mathrm{C}\right)$. The micrograph shows that the serous cells $(\mathrm{Se})$ are in contact with the mucous cells $(\mathrm{Mu})$ which have many secretory granules $(\mathrm{G})$ in the cytoplasm. The nuclei of acinar cells $(\mathrm{Nu})$ are identifiable. However, very little detail of the cellular structure is revealed. $\times 3,000$. Bar, $5 \mu \mathrm{m}$. B: a scanning transmission electron micrograph of a frozen dehydrated section. The micrograph shows that the dramatic improvement in contrast and spacial resolution occurs after the removal of water. The secretory granules $(\mathrm{G})$ of mucous $(\mathrm{Mu})$ and serous (Se) cells are clearly identifiable. The electron density of cytoplasm and nuclei $(\mathrm{Nu})$ of acinar cells decreases extensively after the dehydration. $\times 4,500$. Bar, $4 \mu \mathrm{m}$.

(Fig. 5c and d). The local dry-mass fractions were $20.3 \pm 3.2$ S.D. $\%(n=10)$ and $32.7 \pm 4.1$ S.D. $\%(n=10)$ in the cytoplasm and the secretory granules of resting acinar mucous cells, respectively. Each value was not significantly altered in the stimulating state having a tendency to decrease slightly.

\section{Measurements of elemental concentrations}

The standard curves for elemental concentration peak/back ratio, were made using X-ray spectra from the standard albumin frozen thin sections containing various concentrations of elements $(\mathrm{K}, \mathrm{Ca}, \mathrm{Na}, \mathrm{Cl})$ and 5,20 , or $35 \%$ bovine serum albumin (Fig. 6). There was a linear relationship between the peak/back ratio of the various elements and elemental wet concentrations, and the slopes of lines in 


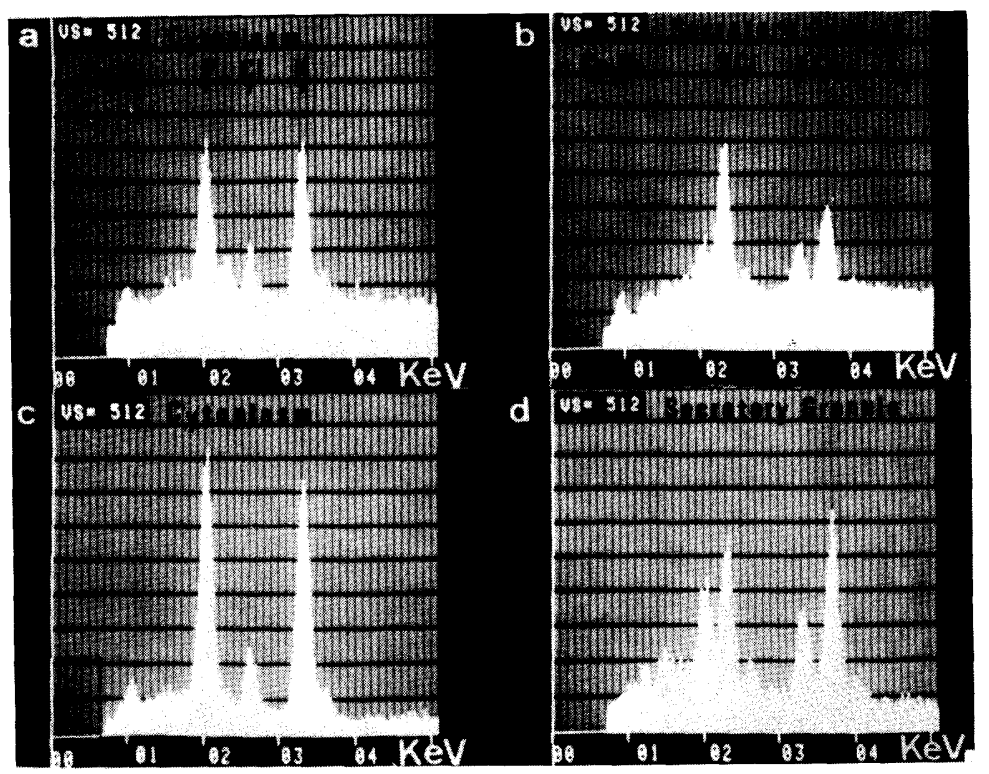

Fig. 5. Representative energy dispersive X-ray spectra of cytoplasm and secretory granule of mucous cell from the frozen hydrated and dehydrated sections of the resting gland. The specimens were prepared as in Fig. 4A and B. Extraneous small peaks of $\mathrm{Cu} \mathrm{L}$ and Si, which originate in the copper grid and the X-ray detector are not subtracted in the spectra. a: X-ray spectrum of cytoplasm from a frozen hydrated section $\left(-130^{\circ} \mathrm{C}\right)$. The high $\mathrm{K}$ and $\mathbf{P}$ peaks are present in the spectrum. Note the high continuum radiation of spectrum. b: X-ray spectrum of secretory granules from a frozen hydrated section $\left(-130^{\circ} \mathrm{C}\right)$. The relatively high $\mathrm{Ca}$ and $\mathrm{S}$ peaks are present in the spectrum. The continuum radiation of spectrum is also high. c: X-ray spectrum of cytoplasm from a frozen dehydrated section. The very high $\mathrm{K}$ and $\mathrm{P}$ peaks are present in the spectrum. Note the very low continuum radiation of spectrum. $\mathrm{d}$ : X-ray spectrum of secretory granule from a frozen dehydrated section. The high $\mathrm{Ca}$ and $\mathrm{S}$ peaks are present in the spectrum. The continuum radiation of spectrum is also low. The local dry-mass fractions were estimated to be $20.4 \pm 3.3$ S.D. $\%(n=5)$ and $32.6 \pm 4.1$ S.D. $\%(n=5)$ in the cytoplasm and the secretory granules of resting acinar mucous cells, respectively.

the graphs of respective elements became steeper as the dry-mass fractions of frozen sections decreased. The concentrations of $\mathrm{Na}, \mathrm{Cl}, \mathrm{K}$, and $\mathrm{Ca}$ in the cytoplasm and secretory granules of acinar mucous cells in the resting and secretory stimulating state, as estimated by the method described above using frozen dried sections of standard albumin solution ( $20 \%$ BSA for cytoplasm and $33 \%$ BSA for secretory granule) and calibration curves for elemental concentration-peak/back ratio, are shown in Table 1. The $\mathrm{Na}, \mathrm{Cl}$, and $\mathrm{Ca}$ concentrations in the cytoplasm as well as the $\mathrm{Na}$ and $\mathrm{Cl}$ in the secretory granules increased, while the $\mathrm{K}$ in the cytoplasm and the $\mathrm{Ca}$ in the granule decreased when the gland was stimulated. 

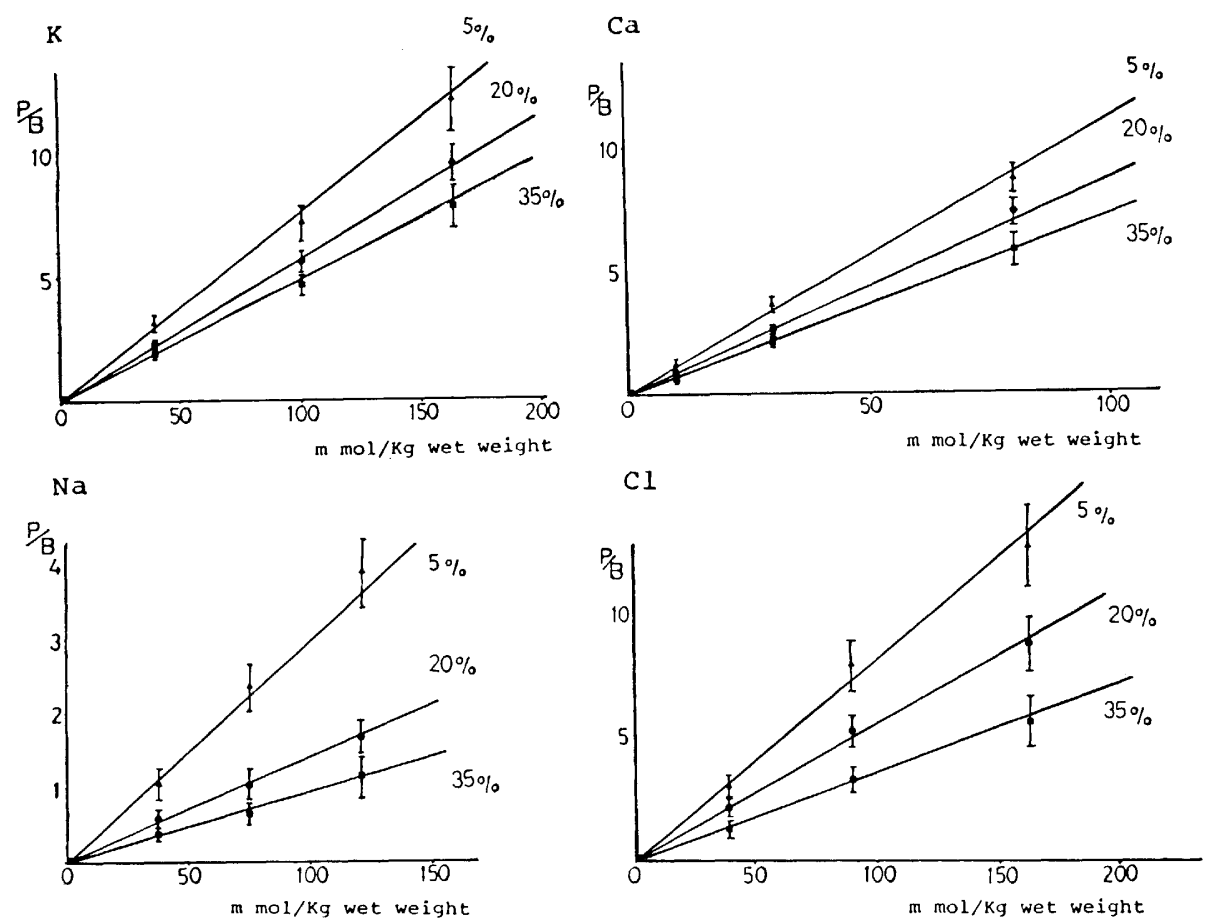

Fig. 6. Standard curves for elemental (K, $\mathrm{Ca}, \mathrm{Na}$, and $\mathrm{Cl})$ concentration-peak/back ratio of $\mathrm{X}$-ray spectra. The graphs were made using X-ray spectra from standard albumin frozen thin sections containing various concentrations of elements $(\mathrm{K}, \mathrm{Ca}, \mathrm{Na}$, and $\mathrm{Cl})$ and 5,20 , or $35 \%$ bovine serum albumin, and show that there is a linear relationship between the peak/back ratio of the various elements and the elemental wet concentrations, and that the slopes of lines in the graphs of respective elements become steeper as the drymass fractions of frozen sections decrease. Five individual experiments were performed (mean value \pm S.E. of mean).

\section{DISCUSSION}

The concentrations of $\mathrm{K}$ in the cytoplasm shown in Table 1 and Fig. 2 are in good agreement with estimations made by other workers (POULSEN and OAKLEY, 1978) and our independent experiments by the ion-selective microelectrode technique. In our microelectrode studies, the value of the $\mathrm{K}$ concentration in the cytoplasm of acinar cells of dog submandibular gland was $121 \pm 17$ S.D. mmol $/ \mathrm{kg}$. cell water, in the resting state and such decreased in the ACh stimulating state. The ion-selective microelectrode responds directly to ionic activities, while in the electron probe $\mathrm{X}$-ray microanalysis, the values refer to the elemental concentration. Therefore, it is reasonable that there should be minor discrepancies between the two different estimations. In our electron probe $\mathrm{X}$-ray microanalysis, the estimations of the elemental concentrations of the extracellular space in the resting 
Table 1. X-ray microprobe measurements of elemental concentrations in the cytoplasm and secretory granules of acinar mucous cells in a resting state and a secretory stimulating state (pilocarpine).

\begin{tabular}{ccc}
\hline & Cytoplasm & Secretory granule \\
\hline Resting state & & $\mathrm{mm} / \mathrm{kg}$ wet weight \\
$\mathrm{Na}$ & $25 \pm 12$ & \\
$\mathrm{Cl}$ & $21 \pm 11$ & $36 \pm 17$ \\
$\mathrm{~K}$ & $115 \pm 37$ & $67 \pm 24$ \\
$\mathrm{Ca}$ & - & $55 \pm 14$ \\
Stimulating state (pilocarpine) & & $49 \pm 16$ \\
$\mathrm{Na}$ & $57 \pm 19$ & \\
$\mathrm{Cl}$ & $54 \pm 21$ & $74 \pm 31$ \\
$\mathrm{~K}$ & $76 \pm 26$ & $87 \pm 29$ \\
$\mathrm{Ca}$ & $9 \pm 5$ & $71 \pm 24$ \\
$\mathrm{M}$ & & $32 \pm 15$ \\
\hline
\end{tabular}

Mean value \pm S.D. of mean $\mathrm{mm} / \mathrm{kg}$ wet weight $(n=22)$. The concentration was read off the graph of elemental concentration-peak/back ratio, which was made using $\mathrm{X}$-ray spectra from the standard albumin frozen thin sections containing $20 \%$ (for measurements in cytoplasm) and $33 \%$ (for measurements in secretory granules) bovine serum albumin and various concentrations of elements $(\mathrm{Ca}, \mathrm{K}, \mathrm{Cl}, \mathrm{Na})$, applying the peak/back ratios from the X-ray spectra of acinar mucous cells in a resting state and a secretory stimulating state (pilocarpine $1 \mathrm{mg} /$ adult $\mathrm{dog}, 1 \mathrm{~min}$ after intravenous injection) to the standard curves of the graph. The scintillation counts of $\mathrm{Cu} L$ peak and $\mathrm{K} \mathrm{K}_{\beta}$ peak were subtracted from those of the $\mathrm{Na}$ and $\mathrm{Ca}$ peaks, respectively. Data represent mean \pm S.D. obtained from 22 separate experiments (22 representative spectra).

state (immersed with Krebs-Henseleit solution containing 20\% BSA: spectrum, Fig. 2d), are as follows; $\mathrm{Na} 112 \pm 29$ S.D. mmol, Cl $135 \pm 24$ S.D. mmol, $\mathrm{K} 8 \pm$ 5 S.D. mmol, $\mathrm{Ca} 3 \pm 2$ S.D. $\mathrm{mmol} / \mathrm{kg}$ wet weight $(n=10)$. As these values are also quite reasonable, our microprobe technique is quantitatively valid. The $\mathrm{P}$ concentration is high in the cytoplasm and nucleus, as shown in Fig. 2. This is probably due to the nucleic acid content of the ribosome and/or chromatin, although the contribution by the other organic and inorganic phosphate cannot be ruled out. The high concentration of $\mathrm{S}$ in the secretory granules shown in these figures may be due to sulfated compounds such as proteoglycan, and secretory proteins such as amylase and mucin. The evidence that the concentration of $\mathrm{Cl}$ in the secretory granules (Fig. 2) is relatively high, is also in good agreement with the data estimated by the ion-selective microelectrode technique suggesting that $\mathrm{Cl}$ is sequestered by the vesicles and/or granules within the cells of amphibian kidney tubules (FUנIMOTo and KuBOTA, 1976).

The secretory granules in the resting state (Fig. $2 b$ ) contained a relatively high content of $\mathrm{Ca}$. Most of this seemed to be in a bound form because the level is too high for free $\mathrm{Ca}$. Experiments using a flame photometric procedure showed that rat submandibular glands as well as saliva contain relatively large amounts of $\mathrm{Ca}$ $(12 \pm 5.0$ S.D. $\mathrm{mmol} / \mathrm{kg} \cdot$ wet tissue, rat submandibular gland). The significance of the evidence that the secretory granules of acinar mucous cells of these subman- 
dibular glands contain $\mathrm{Ca}$ is not clear. One possibility is that the accumulated $\mathrm{Ca}$ as well as $\mathrm{S}$ in the secretory granules may be concerned with the condensation and/or aggregation of secretory protein, as suggested by PALADE (1975) and other workers (WALlach and SCHRAMM, 1971). On the other hand, the migration of secretory granules from basal to apical cytoplasm of acinar cells, and exocytosis of granules into the lumen in the apical portion of the cell and these being associated with the contractile proteins such as microtubules, microfilaments, and myosin in the cytoplasm around the secretory granules (NAKAGAKI et al., 1978), as in the case of posterior silk gland cells (SASAKI and TASHIRO, 1976a, b), may require an appropriate concentration of calcium ion which is leaking out passively from the secretory granule, an intracellular calcium store. Moreover, the membrane of secretory granules may contain a calcium pump such as $\mathrm{Ca}^{2+}, \mathrm{Mg}^{2+}$-dependent ATPase, and it has been proposed that an ATP-dependent calcium sequestration system analogous to the well studied sarcoplasmic reticulum of skeletal muscle is present in microsome or Golgi derived vesicle membrane isolated from dog salivary gland or rat liver cells (WATSON et al., 1974; Chakravarty and Holm Nielsen, 1980; Hodson, 1978). It has also been suggested that the endoplasmic reticulum of L-cells and macrophages has a calcium sequestering system and contains a rel-

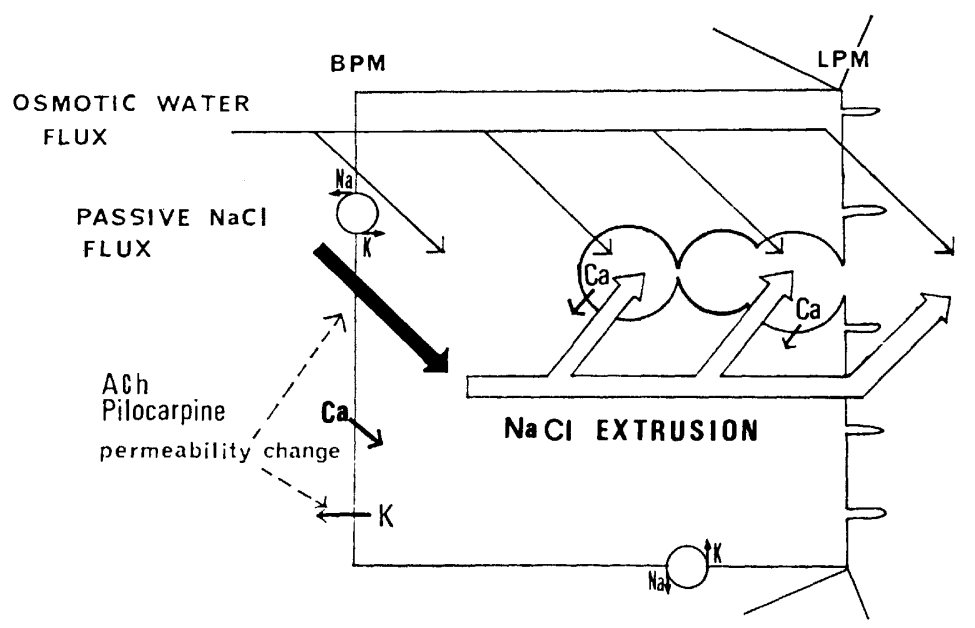

Fig. 7. Schematic drawing of the transport of solute and water in the acinar cell of salivary gland at the secretory stimulating state. It is suggested that the cytoplasmic calcium flowed in from extracellular space and released from secretory granules by the secretory stimulation with ACh or pilocarpine could bring the passive sodium and chloride influx and small potassium outflux in the baso-lateral plasma membrane (BPM), and those induce sodium and chloride extrusion and therefore the osmotic water flux from basal part of acinar cells to the secretory granules and/or glandular lumen, as well as the serial exocytosis of the granules in the luminal side of acinar cells. The Na-K ATPases which maintain the electrochemical potential gradient in the resting state of acinar cells are located in baso-lateral plasma membrane (circles). LPM: luminal plasma membrane. 
atively high concentration of calcium ion in the cisternae and that such is probably involved in the oscillatory membrane potential change and cell motility (HENKART and Nelson, 1979; OKADA et al., 1977). It has been reported that the Goblet cells of the ileum contain such calcium reservoirs (GUPTA and HALL, 1978) and that most of the radioactive $\mathrm{Ca}$ enters the saliva with 5-HT stimulation from prelabelled Calliphora salivary gland cells which have intracellular calcium reservoirs (BERRIDGE and LIPKE, 1979).

We also found that with pilocarpine stimulation there was an increase in the $\mathrm{Na}, \mathrm{Cl}$, and $\mathrm{Ca}$ concentrations in the cytoplasm as well as in the $\mathrm{Na}$ and $\mathrm{Cl}$ concentrations of the secretory granules. The data that this increase became smaller, were also obtained in our perfusion experiments where the glands were incubated in the medium containing low concentraions of $\mathrm{Na}$ and $\mathrm{Cl}$. These evidences suggested that the increase and/or influx of cytoplasmic $\mathrm{Na}$ and $\mathrm{Cl}$ by stimulation could bring about an increase in a sodium-calcium exchange process in the membrane of the secretory granules, an intracellular calcium store, and the extrusion of $\mathrm{Na}$ and $\mathrm{Cl}$ into the secretory granules and lumen, as well as the increase of cytoplasmic $\mathrm{Ca}$. It is also suggested that the $\mathrm{Ca}$ out- $\mathrm{Na}$ in exchange and the $\mathrm{Ca}$ in- $\mathrm{Na}$ out exchange occur in the secretory granules of acinar cells at stimulating and resting states, respectively. Another possibility is that the cytoplasmic $\mathrm{Ca}$ flowed in from extracellular space and released from the granules by stimulation (NIELSEN and Petersen, 1972; NishiYama and Petersen, 1974), could affect the Na channel on the basolateral plasma membrane of acinar cells and induce a passive $\mathrm{Na}$ and $\mathrm{Cl}$ influx, and this influx enhances an active $\mathrm{Na}$ and $\mathrm{Cl}$ extrusion in the apical portion of the cells by a $\mathrm{Na}(\mathrm{Cl})$ pump which may be ouabain insensitive and different from Na-K ATPase distributed on the basolateral plasma membrane maintaining the electrochemical potential gradient of the acinar cell in the resting state (IMAI, 1974; NAKAGAKI et al., 1978).

The $\mathrm{Na}$ and $\mathrm{Cl}$ flux, thus transported in the acinar cells could form the local osmosis in the granules and lumen (DiAmond and Bossert, 1968; GuPTA and HALL, 1979), and the osmotic water flux from the basal part of acinar cells to the granules and the lumen, while the cytoplasmic $\mathrm{Ca}$ induces the serial exocytosis of the granules in the luminal side of acinar cells, as proposed electrophysiologically and electron microscopically for pancreatic acinar cells (KANnO, 1972; Petersen and IwATSUKI, 1978) (Fig. 7). Therefore, the secretory granules which function as an intracellular calcium store in the acinar cells, similar to the sarcoplasmic reticulum of skeletal muscle may be involved in the coupling of the secretory stimulation and intracellular transport or secretion of ions such as $\mathrm{Na}$ and $\mathrm{Cl}$, water, and secretory proteins in the acinar cells of the salivary gland (Douglas and PoISNER, 1963).

We thank Dr. K. Thurau of the University of Munich for encouragement and kind advice. We are also grateful to Dr. Y. Tashiro of the Kansai Medical University, and Dr. M. Fujimoto of the Osaka Medical College for their helpful suggestions and discussion. We also express our thanks to T. Naito of the Osaka Medical College for technical assistance in electron probe X-ray microanalysis and to M. Ohara of Kyushu University for comments on the manuscript. 
This work was supported by a Grant-in-Aid for Scientific Research from the Ministry of Education, Science and Culture, Japan.

\section{REFERENCES}

BERRIDGE, M. J. and LIPKE, H. (1979) Changes in calcium transport across Calliphora salivary glands induced by 5-hydroxytryptamine and cyclic nucleotides. J. Exp. Biol., 78: 137-148.

Chakravarty, N. and Holm Nielsen, E. (1980) $\mathrm{Ca}^{2+}-\mathrm{Mg}^{2+}$-activated adenosine triphosphatase in plasma and granule membranes in non-secreting and secreting mast cells. Exp. Cell Res., 130:175-184.

Diamond, J. M. and Bossert, W. H. (1968) Standing-gradient osmotic flow: A mechanism for coupling of water and solute transport in epithelia. J. Gen. Physiol., 50: 2061.

Dörge, A., Rick, R., Gehring, K., and ThuraU, K. (1978) Preparation of freeze-dried cryosections for quantitative X-ray microanalysis of electrolytes in biological soft tissues. Pflügers Arch., 373: 85-97.

Douglas, W. W. and Poisner, A. (1963) The influence of calcium on the secretory response of the submaxillary gland to acetylcholine or to noradrenaline. J. Physiol. (Lond.), 165: 528541.

Fujimoto, M. and Kubota, T. (1976) Physicochemical properties of a liquid ion exchanger microelectrode and its application to biological fluids. Jpn. J. Physiol., 26: 631-650.

Gupta, B. L., Berridge, M. J., Hall, T. A., and Moreton, R. B. (1978) Electron microprobe and ion-selective microelectrode studies of fluid secretion in the salivary glands of Calliphora. J. Exp. Biol., 72: 216-284.

GuptA, B. L. and HALl, T. A. (1978) Electron microprobe X-ray analysis of calcium. Ann. N. Y. Acad. Sci., 307: 28-51.

GuPTA, B. L. and HALL, T. A. (1979) Quantitative electron probe X-ray microanalysis of electrolyte elements within epithelial tissue compartments. Fed. Proc., 38: 144-153.

Gupta, B. L., Hall, T. A., and Moreton, R. B. (1977) Electron probe microanalysis. In: Transport of Ions and Water in Animals, ed. by Gupta, B. L., Moreton, R. B., Oschman, J. L., and WALl, B. J. Academic Press, Inc., New York, pp. 83-143.

Henkart, M. P. and Nelson, P. G. (1979) Evidence for an intracellular calcium store releasable by surface stimuli in fibroblasts (L cells). J. Gen. Physiol., 73: 655-673.

Hodson, S. (1978) The ATP-dependent concentration of calcium by a Golgi apparatus-rich fraction isolated from rat liver. $J$. Cell Sci., 30: 117-128.

ImAI, Y. (1974) On secretory processes and membrane potential of dog submaxillary gland. In: Secretory Mechanisms of Exocrine Glands, ed. by Thorn, N. A. and Petersen, O. H. Munksgaard, Copenhagen, pp. 199-215.

ImAI, Y., Yoshimura, H., and TAKedA, H. (1972) Water permeability and salt reabsorption in the duct system of the submaxillary gland of dogs. Jpn. J. Physiol., 22: 271-280.

KANNo, T. J. (1972) Calcium-dependent amylase release and electron physiological measurements in cells of the pancreas. J. Physiol. (Lond.), 226: 353-371.

Moreton, R. B., Echlin, P., Gupta, B. L., Hall, T. A., and Weis-Fogh, T. (1974) Preparation of frozen hydrated tissue sections for X-ray microanalysis in the scanning electron microscope. Nature, 247: 113-115.

Nakagaki, I., Goto, T., SASAKi, S., and IMAI, Y. (1978) Histochemical and cytochemical localization of $\left(\mathrm{Na}^{+}-\mathrm{K}^{+}\right)$-activated adenosine triphosphatase in the acini of dog submandibular glands. J. Histochem. Cytochem., 26: 835-845.

Nielsen, S. P. and Petersen, O. H. (1972) Transport of calcium in the perfused submandibular gland of the cat. J. Physiol. (Lond.), 223: 685-697.

Nishiyama, A. and Petersen, O. H. (1974) Effect of calcium on the potential and resistance 
change of the pancreatic acinar cell membrane during the action of acetylcholine. J. Physiol. (Lond.), 238: 55-56p.

OKaDA, Y., Doita, Y., Roy, G., TsuchiYA, W., INOUYE, K., and INOUYE, A (1977) Oscillations of membrane potential in L cells. I. Basic characteristics. J. Membr. Biol., 35: 319-335.

PALADE, G. E. (1975) Intracellular aspects of the process of protein synthesis. Science, 189: 347-357.

Petersen, O. H. (1971) Formation of saliva and potassium transport in the perfused cat submandibular gland. J. Physiol. (Lond.), 216: 129-142.

Petersen, O. H. and Iwatsuki, N. (1978) The role of calcium in pancreatic acinar cell stimulussecretion coupling: An electrophysiological approach. Ann. N. Y. Acad. Sci., 307: 599617.

Poulsen, J. H. and OAKLeY, B., II (1978) Intracellular potassium ion activity in resting and stimulated mouse pancreas and submandibular gland. Proc. R. Soc. Lond. (Biol.), 204: 99-104.

SASAKI, S., NAKAGaki, I., Goto, T., and Imar, Y. (1979) Distribution of electrolytes in exocrine gland cells determined by electron probe X-ray microanalysis. J. Physiol. Soc. Jpn., 41 : 284.

Sasaki, S., Nakagaki, I., Murakami, M., Mori, H., and ImaI, Y. (1980) Distribution of elements in acinar cells of salivary gland determined by electron probe X-ray microanalysis. Proc. Int. Physiol. Sci. XIV (abstract), 3034.

SASAKI, S. and TASHIRO, Y. (1976a) Studies on the posterior silk gland of the silkworm Bombyx mori. V. Electron microscope localization of fibroin in the posterior silk gland at the later stage of the fifth instar. J. Cell Biol., 70: 648-659.

SASAKI, S. and TASHIRO, Y. (1976b) Studies on the posterior silk gland of the silkworm Bombyx mori. VI. Distribution of microtubules in the posterior silk gland cells. J. Cell Biol., 71: 565-574.

Somlyo, A. V., Shuman, H., and Somlyo, A. P. (1977) Elemental distribution in striated muscle and the effects of hypertonicity. J. Cell Biol., 74: 828-857.

WALLACH, D. and SCHRAMM, M. (1971) Calcium and the exportable protein in rat parotid gland. Parallel subcellular distribution and concomitant secretion. Eur. J. Biochem., 21: 433-437.

Watson, E. L., Izutsu, K. T., and Siegel, I. A. (1974) Calcium-stimulated ATPase of dog submandibular gland. Arch. Oral Biol., 19: 13-16.

YounG, J. A. and MARTIN, C. J. (1971) The effect of sympatho- and a parasympathomimetic drug on the electrolyte concentrations of primary and final saliva of the rat submaxillary gland. Pflügers Arch., 327: 285-302. 